\begin{tabular}{|l|l|l|l|l|l|}
\hline 2002 & 271372 & 262824 & 90488 & 77480 & 94856 \\
& & $96.85 \%$ & $34.42 \%$ & $29.47 \%$ & $36.09 \%$ \\
\hline
\end{tabular}

Source: WAEC Statistics Division Lagos.

\title{
Relationship between Senior School Physics Students' Perceptions of Their Physics Teachers' Effectiveness and the Performance in Physics
}

\author{
Dr. (Mrs.) E. O. Omosewo
}

\begin{abstract}
This study investigated the correlation between senior physics student's perception of their physics teachers' effectiveness and the students' performance in physics. One hundred and seventy-seven (177) Senior Secondary School year 3 physics students of six (6) randomly selected secondary schools in Ilorin metropolis took part in the study. The instrument used was a designed questionnaire labeled 'Profile of Dimensions of Effective Physics Teaching'. The students' continuous assessment scores were correlated with perceptions of students about their physics teachers' effectiveness and the students' performance in physics. This finding has implication for physics teaching. The physics teacher must take cognizance of the specific needs of pupils in the planning and delivery of his/her lesson and such leader should devote substantial time to meeting these needs. This is because it has been found from this study and others that have been reviewed that meeting such needs have positive relationship with students' academic performance.
\end{abstract}

\section{Introduction}

The greatest single factor in the teaching process is the teacher. For effective learning to take place, there is the need for teacher's effectiveness especially in science now (more than ever before) that Nigeria is yearning for technological emancipation. One of the general techniques for evaluating instructional effectiveness is the use of students' ratings of instruction (Ali, 1984). Factors contributing to effective teaching include teacher characteristics as well as activities related to teaching which are understanding students, selecting and utilizing instructional materials, management and discipline of students, choosing and implementing appropriate teaching strategies and evaluating student's progress (Brown et al 1982).

The following have been reported to have positive relationships to student test scores on standardized performance tests in reading and mathematics.

a) Teacher focuses clearly on academic goals.

b) Teacher concentrates on allotting the instructional period to instructional tasks rather than socialising.

c) Teacher presents information clearly, organizing instruction by explaining, outlining and reviewing and covers subject matter extensively.

d) Teacher monitors student's progress toward instructional objectives, selecting materials and arranging methods to increases student success.

e) Teacher paces instruction to fit students. 
f) Teacher feedback is quick and targeted on content of instructional tasks. Teacher's management abilities prevent disturbances by encouraging cooperation (Cuban, 1984).

Rosenshine (1979) reviewing a number of studies, specified six instructional functions that have been shown repeatedly to produce improved academic performance as measured by test scores.

1. Checking previous days work

2. Presenting new content/skills

3. Initial student practice

4. Feedback and correctives

5. Student independent practice

6. Weekly and monthly reviews

Similarly, Balogun (1982) found that teacher variables such as provision of feedback to learners, maintenance of good routine schedules and adequate motivation of pupils are positively associated with good certificate results. Akinmade (1988) argued that good management behaviours help high achievement in science.

Science teacher's interest, his help in students' progress, his knowledge of the subject matter, his communication skills, his ability at organising the course and demonstration of a fair evaluation system were found highly ranked by sampled university students and science teacher educators in Ali's (1984) study. From Ali's (1984) study, female science teacher educators perceived effective science teaching to consist of teacher's appearance, demeanour, personality and kindness. Male science teachers were not perceived as being better than their female counterparts in Ali's (1984) study.

This study investigated the relationship between physics students' perception of their physics teachers' effectiveness and their performance in physics. Among the research questions asked in this study are;

1. What is the strength of correlation between performance and perception access of physics students?

2. What is the strength of relationship between performance and perception scores of female physics students?

3 Is there any relationship between perception and performance scores of the male physics students?

\section{Methodology}

This study was a descriptive study of the survey type. The instrument used for the study was a questionnaire named "Profile of Dimensions of Effective Physics Teaching", also the continuous assessment scores of students were collected from the subject teacher in each school. The questionnaire consisted of seven (7) positive and nine (9) negative statements. The statements were categorised under the following broad headings which measured Teacher's personal characteristics, professionalism, and understanding of students; organizing, competence in management, evaluation and discipline of students.

Three of the positive statements are: 
1. Our physics teacher organizes every physics lesson well

2. He/she makes sure that windows and doors of the physics laboratory are opened

3. Our physics teacher punishes us when we disobey him/her

While three of the negative statements include the following:

1. Our physics teacher does not keep records of our work

2. Our physics teacher does not show interest in student's progress

3 Our physics teacher neither demonstrates nor organises physics practical for students.

One hundred and seventy-seven (177) Senior Secondary School year 3 physics students from six (6) randomly selected secondary schools in Ilorin metropolis took part in this study. All the schools are under the Kwara State Educational Management Board. One hundred and thirteen (113) of the students were males and the remaining sixty-four (64) were females. The students have been learning physics for three years. In all the school the physics teachers are first degree university graduates with professional qualification required of them. The schools have laboratory with adequate facilities for physics teaching.

Students were asked to rank their perception based on the questions on a range of 1- 5 interpreted as follows- Strongly Agree (5 marks), Agree (4 marks), Neutral (3 marks), Disagree (2 marks) and strongly Disagreed (1 mark). In this way, a maximum of 80 marks and a minimum of 16 were possible on the questionnaire.

The reliability of the instrument was established by calculating the product moment co-efficient of correlation of the perception and continuous assessment scores of SS 3 students in a school in Ilorin Township over a time lag of four weeks. The reliability co-efficient of the instrument was 0.72 .

\section{Results}

Three research questions were generated for the study. The three research questions were answered by subjecting the two sets of scores (perception scores and achievement scores) to measures of relationship using Pearson Product Moment Correlation Co-efficient.

\section{Research Question 1}

What is the correlation between achievement and perception scores of students?

When the two sets of scores were subjected to measures of relationship using Pearson Product Moment Correlation Co-efficient the value of 0.04482 was obtained showing that the strength between perception scores of students and their achievement scores is 0.04482 and it is a positive relationship. This means that the higher the perception of the students about their physics teachers' effectiveness, the higher their performance scores. The reverse can also be true. The strength of correlation of the two scores is 0.5536 which is a high value (see Table 1 ).

Table 1: Results of Correlation Analysis Performance Students with the Perception Scores of Their Physics Teachers Effectiveness

\begin{tabular}{|l|l|l|l|l|l|l|}
\hline Variable & $\mathbf{N}$ & Mean & $\begin{array}{l}\text { Standard } \\
\text { Deviation }\end{array}$ & $\begin{array}{l}\text { Sum of } \\
\text { squares }\end{array}$ & $\mathbf{R}$ & $\begin{array}{l}\text { Eta } \\
\text { (A) }\end{array}$ \\
\hline Achievement scores & 177 & 43.54802 & 18.39896 & 7708 & 0.04482 & 0.5536 \\
\hline Perception scores & 177 & 42.75141 & 5.91275 & 7567 & & \\
\hline
\end{tabular}




\section{Research Question 2}

students?

What is the relationship between achievement and perception scores of female

Table 2 revealed that the co-efficient value of research question 2 was 0.02154 and its strength of correlation is 0.8658 . This means that the relationship is positive and its strength of correlation is high showing that female physics students perceive that their teachers' effectiveness can influence to a large extent their achievement in physics.

Table 2: Result of Correlational Analysis of Female Student's Performance Scores in Physics with

the Perception Scores

\begin{tabular}{|l|l|l|l|l|l|l|}
\hline Variable & $\mathbf{N}$ & Mean & $\begin{array}{l}\text { Standard } \\
\text { Deviation }\end{array}$ & $\begin{array}{l}\text { Sum of } \\
\text { squares }\end{array}$ & R & $\begin{array}{l}\text { Eta Value } \\
\text { (A) }\end{array}$ \\
\hline Achievement scores & 64 & 44.00000 & 20.07684 & 2816 & 0.02154 & 0.8658 \\
\hline Perception scores & 64 & 43.25000 & 5.76250 & 2768 & & \\
\hline
\end{tabular}

\section{Research Question 3} students?

Is there any relationship between perception and performance scores of male

On this research question a co-efficient value of 0.05778 was obtained while its strength of correlation 0.5433 . This co-efficient value shows that the relationship is positive and also significant. Male students' perception about their physics teachers' effectiveness has influence on their achievement in physics as showed in Table 3.

Table 3: Result of Correlation of Performance Scores of Male Students with their Perception Scores of their Physics Teachers' Effectiveness

\begin{tabular}{|l|l|l|l|l|l|l|}
\hline Variable & $\mathbf{N}$ & Mean & $\begin{array}{l}\text { Standard } \\
\text { Deviation }\end{array}$ & $\begin{array}{l}\text { Sum of } \\
\text { squares }\end{array}$ & $\mathbf{R}$ & $\begin{array}{l}\text { Eta Value } \\
(\mathbf{A})\end{array}$ \\
\hline Achievement scores & 113 & 43.29204 & 17.46562 & 4892 & 0.05778 & 0.05433 \\
\hline Perception scores & 113 & 42.46903 & 6.00308 & 4799 & & \\
\hline
\end{tabular}

\section{Summary of Findings}

The findings of this study are as follows.

- The correlation between performance in physics of the sampled students and their perception about their physics teachers' effectiveness in 0.04482 (positive) and it is 0.5536 strong.

- The correlation between performance in physics of female students and their perception about their physics teachers' effectiveness is 0.02154 (positive) and it is 0.8658 strong. 
- The correlation between performance in physics of male students and their perception about their physics teachers' effectiveness is 0.05778 (positive) and it is 0.5433 strong.

\section{Discussion and Recommendations}

In this study, efforts were made to find the relationship between students' perception about their physics teachers' effectiveness and their performance in physics. Three research questions were generated and they were answered using Pearson Product Moment Correlation Co-efficient. Research question one was confirmed by the result on Table 1. Research question two was confirmed by the result on Table 2 while the third research question was confirmed by the result on Table 3 .

These results show that there is positive correlation between students' perception about their physics teachers' effectiveness and their performance in physics. Their levels of performance are not the same for the three groups, that is, all students male students and female students. A comparison of results in Table 1,2 and 3 shows that the correlation between male physics students' performance and their perception about their physics teachers' effectiveness was the highest of the three groups. What is significant in this study is that performance appears to be a function of the students' perception of their teachers' effectiveness.

It therefore appears that the higher the students' perception about their physics teachers' effectiveness the better their performance in physics. The findings of this study agree with those of Rosenshine (1979) and Cuban (1984). Also, they agree with Balogun's (1982) study, which found that teacher variables such as provision of feedback to learners, maintenance of good routine schedules and adequate motivation of pupils are positively associated with good certificate results. In Ali's (1984) study, female science teacher educators perceived effective science teaching to consist teacher's appearance, demeanour, personality and kindness. This study did not sample female science educators but female science students. It was found that their performance scores had a high strength of correlation when correlated with their perception about their physics teachers' effectiveness. The findings of this study also agree with Akinmade's (1988) studywhich assert that, good management behaviours by teachers help high performance in science.

The implication of this study for physics teaching is clear. The physics teacher must take cognizance of the specific needs of pupils in the planning and the delivery of his/her lessons, and devotes much of the total teaching time to meeting these needs. It may not be easy but with much effort the task can be accomplished. Teachers deal with pupils with varying needs, interest, abilities, rates of learning, degrees of retentions and emotions. They also come from different cultural and economic backgrounds. Dealing with pupils with such individual differences in the classroom is a great task for every teacher.

Perhaps it may be worthwhile to recommend organizational practices to help classroom instruction. Some of these practices include individualization, open school, computer assisted instruction, microteaching, contract, microteaching and team teaching (Olorundare, 1999). These organizational practices have their strengths in the sense that the individual difference of learners are taken into consideration and instruction on a oneto-one basis between teacher and pupils is possible with these practices. These arrangements are expensive to run. Therefore, governments at local, state and federal 
levels should commit reasonable funds to education. Also, philanthropists should cultivate the habit of donating money for educating pupils because government alone cannot fund education effectively.

Efforts should also be made by the government to provide incentives for the few available physics teachers by way of payment of enhanced science allowance, prompt promotion when due, as well as adequately equipping physics laboratories. Where some aids can be improvised, money should be made available to the teachers for such improvisation.

Seminars and workshop should be organized more frequently for physics teachers on ethics of teaching as well as in the subject matter content. Seminars and workshop have not been organized as often as they should for teachers of all subjects, particularly for physics teachers. The merits of such workshops cannot be over stressed and money spent on such a venture is not a waste. Science teachers, particularly physics teachers, should be sponsored to conferences such as conferences of science teachers' association of Nigeria. Nigeria Institute of Physics, amongst others. All effort should be made by physics teachers to exhibit appropriate behaviour in class as it has been found from this study as well as past studies that such appropriate behaviours had positive relationship with students' academic performance.

\section{References}

Agboola, B. S.and Osibodu, B. M. (1985): A study of the relationship between teachers Behaviors aimed at individualizing instruction and pupils' achievement in mathematics class. Journal of Research in Curriculum, vol.3 (2), p.3-15.

Akinmade, C. T. O. (1988). The impact of science teacher management behaviors on Student's learning outcomes, Nigerian Educational Forum, 11(1), 95-100.

Ali, A. (1984). Dimensions of effective science teaching as perceived by University students and science teacher educators in Nigeria. Journal of Research in Curriculum, 2(2), 115-125.

Balogun, T. A. (1982). Science society and science teaching effectiveness in Nigeria, Journal of Science Teachers' Association of Nigeria, 21(1), 14-20.

Brown, R. N.; Oke, F. E. \& Brown, D. P. (1982). Curriculum and instruction. An Introduction to methods of teaching, London, Macmillan Press Ltd.

Cuban, L. (1984). How teachers taught, New York, Longman.

Olorundare, A. S. (1999). Principles and Practice of Instruction. An unpublished paper in The department of Curriculum Studies and Educational Technology, University of

Ilorin, Ilorin, Nigeria. 


\section{Guide To Authors}

Manuscripts should be in English type written on one side of the paper only, 12-font size, doublespaced with wide margins. All papers should be numbered consecutively. Manuscripts should not exceed 20 pages, including abstract, tables, figures and plates.

The first page ( title page) of the manuscript should contain the following; (i) the title, (ii) the name (s) of the author (s), (iii) Institutional affiliation (s) of the authors (s), (iv) Correspondence Address of the lead author. The second page of the manuscript should contain the title, the name(s), an abstract not more than 100 words and maximum of 5 key words; followed by the body of the article.

\section{Citation and References}

\section{Within the text}

references to publications shall follow the APA format such as:

"Gashe (1992) reported that................"

"This problem has been a subject in the literature before (Alexander and Levis, 2003)"

Or Alexander et al (2003) if more than two authors.

The author should make sure that there is a strict one-to-one correspondence between the names (years) in the text and those on the reference list. At the end of the manuscript (after any appendices), the complete references should be listed as:

\section{For books and monographs}

Tabachnik B and Fidell L.S. (1996) Using Multivariate Statistics, Harper Collins Publisher, New

York.

For Journals and Periodicals

Mbaku J.M. (1989) "Patterns and Levels of life in Sahel West Africa Since 1960'S" African Insight

Vol.19. No 1 pp.38-47.

\section{For Contribution to collective Works}

Charnley A.K. (1992) "Mechanisms of Fungal pathogenesis in insects with particular references to Locusts" in Lomer C.J. and Prior c. (eds)- Biological control of Locusts and Grasshoppers: Proceedings of an International Conference held at Cotonou, Benin, pp181-190.

\section{Submission of Manuscript.}

Manuscripts should be sent in duplicate, accompanied by a diskett copy to

Dr. B.J. Ojo

The Editor,

African Research Review

Pedagogical Science Department

Bahir Dar University

Bahir Dar, Ethiopia.

E-mail - afrr_ethio@yahoo.com 